\title{
KEDUDUKAN DAN SUSUNAN PENGADILAN TATA USAHA NEGARA
}

\author{
ANDEGA ARGA YANOTTAMA \\ N o BP : 1910003600023 \\ Kelas : $3 \mathrm{H} 4$
}

I. PENDAHULUAN

A. Latar Belakang

Pada umumnya kedudukan Pengadilan Tata Usaha Negara (PTUN) suatu negara selaras dengan sistem hukum apa yang dianutnya. Sistem hukum dapat dikelompokkan ke dalam kategori sistem hukum induk (parent legal system) atau sistem hukum utama (major legal system) seperti sistem Civil Law disebut juga sistem hukum kontinental, sistem hukum kodifikasi atau dengan istilah negara hukum rechtstaat dan Common Law disebut juga dengan sistem hukum Anglo-Saxon, sistem hukum preseden atau dengan istilah negara hukum rule of law. Adapun negara-negara yang karakteristiknya mendekati ciri-ciri hukum utama, secara sepintas dapat dikatakan sama dengan hukum utama tersebut.

Pembagian sistem-sistem hukum menjadi keluarga-keluarga hukum mempunyaibanyak tujuan, menurut Michael Bogdan tujuan utamanya adalah instrumen pedagogis yang sangat dasar untuk memudahkan studi perbandingan hukum. Dalam tulisan ini digunakan untuk membandingkan metode-metode dasar pemikiran hukum, konsep- konsep hukum dan terminologi hukum yang berkaitan dengan PTUN.

Di negara-negara sistem hukum Common Law menganut sistem unity of jurisdiction sehingga tidak mengenal eksistensi PTUN yang secara struktural dan organisatoris terpisah dari peradilan umum. Sedangkan dalam sistem hukum Civil Law justru dikenal adanya pemisahan antara peradilan umum dan PTUN (sistem duality of jurisdiction) misalnya, di Prancis, Belanda, Jerman, Italia dan negara-negara bekas jajahannya di Benua Afrika, Amerika Latin, dan Asia, termasuk Indonesia. Namun meski sama-sama menerapkan sistem 
Civil Law, masih juga terdapat perbedaan diantara negara- negara tersebut ihwal variasi dalam struktur organisasinya dan prosedur hukumnya.

Di Indonesia PTUN merupakan bagian dari kekuasaan kehakiman yang secara struktur organisasi berada di bawah Mahkamah Agung dan tidak berdiri sendiri seperti pada negaranegara sistem Civil Law pada umumnya. Karena berada di bawah Mahkamah Agung maka pembinaan teknis peradilan, organisasi, administrasi, dan finansial Pengadilan dilakukan oleh Mahkamah Agung. Secara normatif PTUN bukan pengadilan yang mandiri di luar kekuasaan kehakiman (yudisial), sehingga sistem penyelesaian sengketa tata usaha negara mengikuti pola penyelesaian sengketa perdata yang mengenal istilah pengadilan tingkat pertama, tingkat banding, kasasi dan peninjauan kembali.

\section{B. Pembahasan}

\section{A. Sejarah Pembentukan PTUN}

Pada awalnya konstitusi Indonesia (UUD 1945) tidak mengenal eksistensi PTUN, istilah Peradilan ini secara formal diperkenalkan oleh UU No. 19 Tahun 1948 tentang Susunan dan Kekuasaan Badan-Badan Kehakiman dan Kejaksaan, ihwal PTUN diatur dalam Bab III tentang "Peradilan Tata Usaha Pemerintah" yang terdiri atas dua pasal yaitu pasal 66 dan Pasal 67 undang-undang tersebut.

Untuk membentuk PTUN di Indonesia pemerintah telah melakukan upayamempelajari sumber utama rezim administratif yaitu Prancis, selain Perancis juga dipelajari sistem peradilan administrasi di Belanda. St. Munadjat Danusaputro selaku asisten khusus Menteri Kehakiman Bidang Hukum Lingkungan-Lingkungan Internasional pada bulan Oktober 1975 ditugaskan oleh Menteri Kehakiman RI untuk meninjau Conseil d'Etat selama dua minggu. Namun setelah dipelajari ternyata sistem PTUN di Prancis dijalankan oleh eksekutif bukan yudikatif. Secara struktur organisasi sistem PTUN di Prancis tidak dapat diterapkan di Indonesia karena Pasal 24 UUD 1945 jo. Undang-Undang No. 14 Tahun 1970 tentang Ketentuan-ketentuan Pokok Kekuasaan Kehakiman pada Pasal 10 ayat (1) dan ayat (2) mengamanatkan bahwa PTUN berada dalam kekuasaan kehakiman di bawah mahkamah AgunG.Oleh karena sistem peradilan tata usaha negara di Prancis tidak bisa diterapkan,maka pemerintah memandang cocok dengan sistem peradilan tata usaha negara sebagaimana diterapkan oleh Belanda. Di Belanda tidak ada lembaga PTUN yang mandiri terpisah dari peradilan umum seperti di Prancis. Di Belanda dikenal dua fase 
proses penyelesaian sengketa yaitu administrative review dan judicial review, dua fase inilah yang disebut sebagai peradilan tata usaha negara.

\section{Struktur PTUN}

Sebagai negara yang terbentuk di zaman modern perkembangan negara hukumIndonesia juga mendapat pengaruh dari sistem Common Law. Ahmad Ali mengatakansistem hukum Indonesia adalah mix legal system sedangkan Mahfud M.D. dan Bagir Manan mengistilahkan Negara Hukum Indonesia berparadigma Prismatik yaitu kolaborasi dari rechstaat dan rule of law, kemudian Muhammad Thahir Azhari menyimpulkan bahwa negara hukum Indonesia adalah konsep negara hukum Pancasila.

PTUN di Indonesia terpisah dari peradilan umum tetapi sama-sama berpuncak ke Mahkamah Agung sebagaimana terlihat dalam rumusan Pasal 24 UUD 1945, yang kaidahnya sebagai berikut:

(1) Kekuasaan kehakiman merupakan kekuasaan yang merdeka untuk menyelenggarakan peradilan guna menegakkan hukum dan keadilan.

(2) Kekuasaan kehakiman dilakukan oleh sebuah Mahkamah Agung dan badan peradilan yang berada di bawahnya dalam lingkungan peradilan umum, lingkungan peradilan agama, lingkungan peradilan militer, lingkungan peradilan tata usaha negara, dan oleh sebuah Mahkamah Konstitusi.

(3) Badan-badanlain yang fungsinya berkaitan dengan kekuasaan kehakiman diatur dalam undang-undang.

Pasal 18 UU No. 48 Tahun 2009 tentang Kekuasaan kehakiman menetapkan: Kekuasaan kehakiman dilakukan oleh sebuah Mahkamah Agung dan badan peradilan yang berada di bawahnya dalam lingkungan peradilan umum, lingkungan peradilan agama, lingkungan peradilan militer, lingkungan peradilan tata usaha negara, dan oleh sebuah Mahkamah Konstitusi.

Pasal 20 ayat (1) UU No. 48 Tahun 2009 tentang Kekuasaan kehakiman menetapkan: "Mahkamah Agung merupakan pengadilan negara tertinggi dari badan 
peradilan yang berada di dalam keempat lingkungan peradilan sebagaimana dimaksud dalam Pasal 18".Dari rumusan pasal-pasal di atas dapat digambarkan struktur peradilan tata usaha negara di Indonesia sebagai berikut :

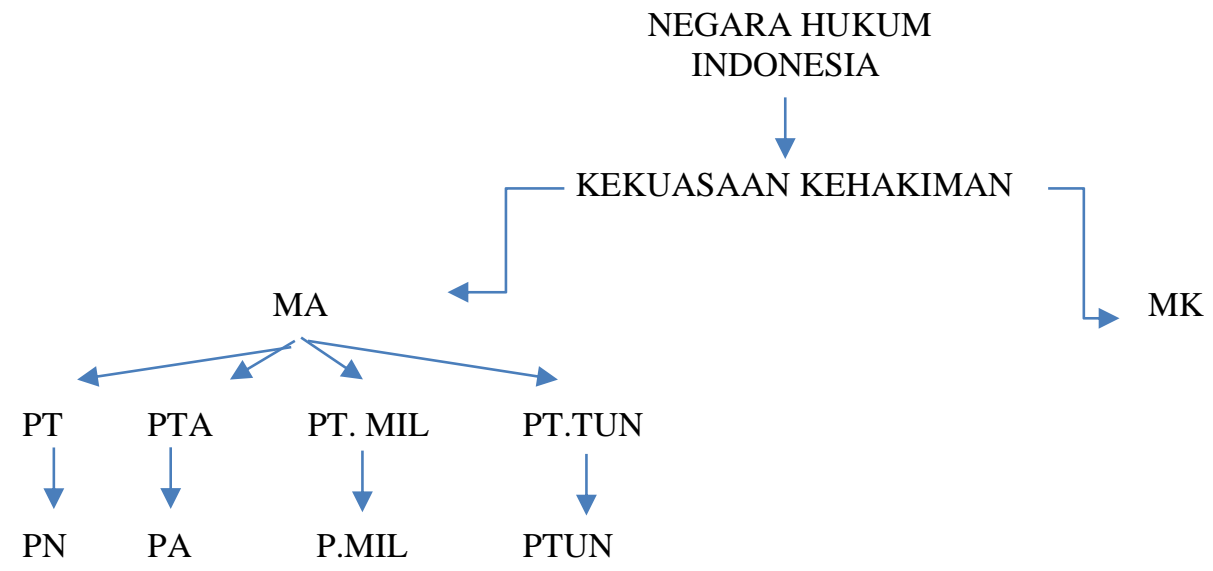

Dari gambar struktur PTUN di atas, sistem PTUN di Indonesia merupakan kasus yang menarik, tidak mengikuti sepenuhnya sistem PTUN di negara-negara Civil Law yang memiliki dua set peradilan (duality of jurisdiction) seperti negara Prancis dan negara-negara yang menganut sistem Civil Law pada umumnya.

Struktur PTUN di Indonesia lebih mengarah kepada konsep unity of jurisdiction sebagaimana diterapkan di negara-negara sistem Common Law yang tidak mengenal eksistensi PTUN secara mandiri, sengketa tata usaha negara diadili oleh pengadilan umum yang berpuncak kepada Mahkamah Agung. Meskipun demikian menurut Yodi Martono Wahyunadi bukan berarti PTUN Indonesia menganut sistem Common Law karena dalam pelaksanaan fungsinya PTUN lebih cenderung pada konsep Civil Law yang memposisikan Pejabat Pemerintahan tidak sejajar dihadapan pengadilan.

Karena posisi PTUN dan peradilan umum dalam struktur peradilan di Indonesia adalah sama-sama menjalankan kekuasaan kehakiman di bawah Mahkamah Agung, dimana pemisahan keduanya sebatas pada instansi pengadilan tingkat pertama dan pengadilan tingkat banding saja, maka menurut penulis konsep sistem PTUN di Indoensia mendekati sistem unity of jurisdiction.

\section{Fungsi PTUN}

PTUN bertugas dan berwenang memeriksa, memutus, dan menyelesaikan sengketa Tata Usaha Negara. Sengketa dimaksud adalah sengketa antara warga masyarakat dengan 
pejabat pemerintahan sebagai akibat dikeluarkannya keputusan tata usaha negara, termasuk sengketa kepegawaian. Inti dari fungsi PTUN adalah lembaga yang disediakan untuk menyelesaikan sengketa antara pemerintah dan warga masyarakat dalam bidang hukum publik.

Prinsip khusus PTUN misalnya pertama: prinsip pembuktian bebas (Vrij bewijs) hakim bebas membebankan pembuktian kepada para pihak yang dianggap kompeten menghadirkan bukti yang dibutuhkan. Kedua: prinsip keaktipan hakim (actieve rechter); dan ketiga: prinsip erga omnes. Prinsip erga omnes dalam sengketa tata usaha negara maksudnya adalah bahwa pejabat pemerintahan dalam membuat suatu keputusan sudah mempertimbangkan semua kepentingan masyarakat (kepentingan umum) sehingga walaupun keputusan bersifat konkrit, individual dan final, untuk itu apabila keputusan ini dipermasalahkan di PTUN maka putusan PTUN nantinya bersifat erga omnes berlaku untuk semua orang.

Dilain pihak, karena PTUN menjalankan fungsi yudisial murni maka terikat dengan prinsip-prinsip peradilan terutama prinsip pengujian recthmatigheid dan larangan menguji doelmatigheid. Dalam konteks ini hakim PTUN tidak mengkonsentrasikanpenilaiannya terhadap isi atau maksud dari keputusan tetapi yang menjadi fokus penilaianadalah bagaimana proSes pengambilan keputusan", hal ini menjadi tantangan besar dari keadilan yang ingin dicapai oleh warga masyarakat.

\section{PENUTUP}

PTUN di Indonesia merupakan kombinasi dari kedua sistem tersebut karena bila dilihat dari fungsi dan struktur organisasi PTUN lebih cenderung kepada sistem unity of jurisdiction dengan alasan bahwa PTUN di Indonesia menjalankan fungsi yudisial murni yang secara struktur organisasi berada di bawah Mahkamah Agung, akan tetapi bila dilihat dari aspek prinsip-prinsip penyelesaian sengketanya lebih kepada sistem duality of jurisdiction terutama prinsip yang membedakan secara tegas antara hukum perdata dan hukum publik serta menempatkan pemerintah secara istimewa dihadapan pengadilan.

Pembedaan antara sistem unity of jurisdiction dan duality of jurisdiction setidaknya mencakup struktur organisasi, metode-metode dasar pemikiran hukum, konsep-konsep hukum. Pada sistem unity of jurisdiction, sengketa tata usaha negara dijalankan oleh yudisial murni (Mahkamah Agung) dengan segala prinsip-prinsipnya, sedangkan pada sistem duality of 
jurisdiction sengketa tata usaha negara diselesaikan melalui lembaga sendiri yaitu PTUN yang secara struktur organisasi bukan berada di bawah Mahkamah Agung sehingga tidak sepenuhnya terikat pada doktrin-doktrin peradilan pada umumnya.

\section{DAFTAR PUSTAKA}

\section{Buku}

Badan Pembinaan Hukum Nasional (BPHN), Simposium Peradilan Tata Usaha Negara, Cetakan Pertama, Bandung: Binacipta, 1977.

Basah, Sjachran, Hukum Acara Pengadilan dalam Lingkungan Peradilan Administrasi (HAPLA), cetakan pertama, Jakarta: Rajawali Press, 1989.

Bogdan, Michael, Comparative Law, Sweden, Norstedts Juridik Norway: Kluwer and Taxation Publishers, 1994.

Brown, L. Neville and John S. Bell, French Administrative Law, Fifth Edition, Oxford New York: Oxford University Press, 2003.

Budiarjo, Miriam, Dasar-Dasar Ilmu Politik, cetakan kesebelas. Jakarta: PT. Gramedia Pustaka Utama, 2015.

Cruz, Peter de, Perbandingan Sistem Hukum Common Law, Civil Law dan Sosialits Law, diterjemahkan oleh Narulita Yusron, Cetakan I, Bandung: Nusa Media, 2010

Dicey, A.V, Introduction the Study of the Law of the Constitution, diterjemahkan oleh Nurhadi, Pengantar Studi HukumKonstitusi, cetakan IV. Bandung: Nusamedia, 2014.

Frydman, M. Patrick, $11^{\text {th }}$ Annual AIJA Tribunals Conference, in Association with the Council of Australian Tribunals, 5-6 June 2008, Watermark Hotel \& Spa, Surfers Paradise, Queensland.

Lotulung, Paulus Effendi, Hukum Tata Usaha Negara dan Kekuasaan, Penerbit Salemba Humanika, Jakarta, 2013.

Manan, Bagir, Prospek Peradilan Tata Usaha Negara di Indonesia, disampaikan dalam Rapat KoordinasiNasional MA-RI Dengan Jajaran Peradilan Tata Usaha Negara Se Indonesia Tahun 2008, di Hotel Panghegar Bandung, 14-16 Januari 2008.

Marzuki, Peter Mahmud, Pebelitian Hukum, Edisi Revisi, Cetakan ke-9, Jakarta, Prenadamedia Group, 2014.

MD, Moh. Mahfud, Konstitusi dan Hukum dalam Kontroversi Isu. Jakarta: RajaGrafindo Persada, 2010. 